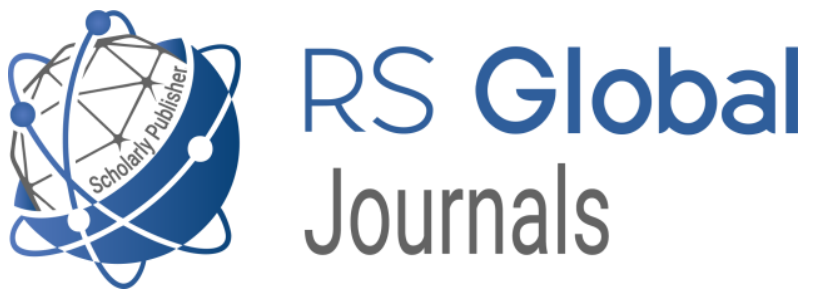

Scholarly Publisher

RS Global Sp. z O.O.

ISNI: 0000000484952390

Dolna 17, Warsaw, Poland 00-773

Tel: +48226022703

Email: editorial_office@rsglobal.pl

JOURNAL International Journal of Innovative Technologies in Social Science

p-ISSN 2544-9338

e-ISSN 2544-9435

PUBLISHER RS Global Sp. z O.O., Poland

ARTICLE TITLE THE IMPORTANCE OF NAMES IN T. S. ELIOT'S POETRY

AUTHOR(S) Nurlana Akhundova

Nurlana Akhundova. (2020) The Importance of Names in T. S.

ARTICLE INFO Eliot's Poetry. International Journal of Innovative Technologies in Social Science. 6(27).

doi: $10.31435 /$ rsglobal_ijitss/30092020/7194

DOI https://doi.org/10.31435/rsglobal_ijitss/30092020/7194

RECEIVED 20 July 2020

ACCEPTED 31 August 2020

PUBLISHED 04 September 2020

LICENSE This work is licensed under a Creative Commons Attribution

4.0 International License.

(C) The author(s) 2020. This publication is an open access article. 


\title{
THE IMPORTANCE OF NAMES IN T. S. ELIOT'S POETRY
}

\author{
Nurlana Akhundova, Ph.D. student at Azerbaijan University of Languages, English Language \\ Lecturer at Baku Engineering University, Azerbaijan
}

DOI: https://doi.org/10.31435/rsglobal_ijitss/30092020/7194

\section{ARTICLE INFO}

Received 20 July 2020

Accepted 31 August 2020

Published 04 September 2020

\section{KEYWORDS}

names, personality, society, Christianity, music, myth, places.

\begin{abstract}
Names are of great importance in Thomas Stearns Eliot's poetry. He chooses titles to provide a general overview of a particular poem. The author used a variety of names in his literary activity to intrigue the reader's curiosity. In this article, we will discuss the titles related to musical terms. Here proper names will be analyzed in detail. Names the poet utilizes in his poetry are of different origins: some of them are mythological heroes, others are formed just by combining the letters, and some are acquaintances or place names. Due to T. Eliot's conversion, the naming of personages underwent a religious transformation. The character names with negative meanings preoccupy his early poems. They are associated with animals who only rely on their basic instincts, the living deads who only exist physically, infertile and unloving creatures that betray each other. After changing of faith, he added Christian names to power his poetry. We will lay stress on the formation, usage, relation of titles, and analyze how they identify the poetry.
\end{abstract}

Citation: Nurlana Akhundova. (2020) The Importance of Names in T. S. Eliot's Poetry. International Journal of Innovative Technologies in Social Science. 6(27). doi: 10.31435/rsglobal_ijitss/30092020/7194

Copyright: (C) 2020 Nurlana Akhundova. This is an open-access article distributed under the terms of the Creative Commons Attribution License (CC BY). The use, distribution or reproduction in other forums is permitted, provided the original author(s) or licensor are credited and that the original publication in this journal is cited, in accordance with accepted academic practice. No use, distribution or reproduction is permitted which does not comply with these terms.

Introduction. Titles in literature are one of the key factors in conveying information to the reader. The names might serve to predict information about the content of the literary work and the personality traits of the characters. In other words, the names reveal the character's national and cultural affiliation in a certain sense of the time and place in which he lived. Thomas Stearns Eliot used different titles in poetry, which lead to contradictory ideas among scholars and researchers. Thus, the author guided the readers and researchers in the discovery of conflicting points and in covering the semantic meaning by using various names. As we travel into the inner world of the images created by the poet, we witness the direct or indirect connection of the names with the outside world. Sometimes the poet uses titles that do not exist, as a product of his imagination by combining different letters. In general, in T. Eliot's poetry, names play an important role in revealing the characteristics and the temperament of the personage.

Discussion. In T.S. Eliot's poetry, the titles sometimes are called by musical terms. Poems such as "The Love Song of J. Alfred Prufrock," "Rhapsody on a Windy Night," "Preludes," and "Four Quartets" mention different terms in music theory. The poem "Rhapsody on a Windy Night" was written in 1915 at a time when European society and culture were in decline. As we know, a rhapsody is a free-flowing structured instrumental work written on the base of folk songs and dances. It usually expresses strong and romantic feelings. Although free rhyme is preserved in Eliot's poem, the reader feels an irony against festivity. The poem, written in a free form, is composed of irregularly arranged different images, repetitions, and inappropriate rhymes. Although rhapsody is associated with ideas such as passion and extreme enthusiasm, these feelings are not reflected in the poem. The main themes are distrust of God, alienation, people's hatred of each other, and less communication. "Preludes" was published in 1917 in his first book of poems, "Prufrock and Other Observations." The prelude is a 
short introduction before a long piece in music. The prologue in literature and the prelude in music play the role of introduction and create the basis for the development of subsequent events. The verse depicts the worries of city life in a short period. To be more precise, the events in the poem take place in one day. The title of the poem can be related to the beginning of the poet's literary activity. Thus, this work laid the foundation for the writing of "The Waste Land," which brought him fame in the world literature. It is no coincidence that the poem "The Waste Land" also reflects the burden of city life and the alienated people living there.

Some of the titles in T.S. Eliot's poetry are directly related to the names of the protagonist or anti-heroes, such as "The Love Song of J. Alfred Prufrock," "Gerontion," "Mr. Apollinax," "Aunt Helen," "Sweeney Erect," "Sweeney Among the Nightingales" and others.

The title of the poem, "Mr. Apollinax," is reminiscent of Apollo in Greek mythology. Apollo was one of the oldest gods in Greece and used to be the god who protected the flocks. Later, he was considered the patron saint of immigrants and Greek colonies, art, poetry, and music.

In a two-volume book co-edited by Christopher Ricks and Jim McQueen, the title Mr. Apollinax was claimed to be taken from a place called Appollis Arc, which is mentioned in Greek mythology. It should be noted that Appolonis Arc is the entrance to the cave where Sibyl received her prophecy. Taking this into account, we assume that the poem is either about a man of divine power or a prophet who makes wise decisions. The poem begins with a professor's visit named Apollinax to the United States and a meeting with Mrs. Phlaccus and Professor Channing-Cheetah. Valerie, who edited Eliot's letters, claims that Mr. Apollinax was B. Russell, a Cambridge philosopher. Eliot met Russell while studying at Harvard University. The philosopher, who played a key role in Eliot's philosophical views on life, invited him to defend his doctoral dissertation at Oxford University. Thanks to him, Eliot decided to come to Britain and live here for a lifetime. He later met and married a woman named Vivienne. During Eliot's six-week trip to the United States, a love affair begins between Vivienne and Russell. The illicit relationship between Vivienne and Russell continues after the husband and wife rent the philosopher's house. It is not in vain that Apollinax is likened to Priapus in poetry. Priapus is a mythological character embodying high sexual desire. Unable to suppress his primal instincts like Priapus, Russell had a love affair with his friend's wife.

The character Sweeney is considered one of the main figures in T.S. Eliot's poetry. Poems, such as "Sweeney Erect," "Mr. Eliot's Sunday Morning Service," and "Sweeney Among the Nightingales," written between 1918 and 1919, portray him in a bad light. The name Sweeney is also mentioned in the second section of the poem "The Waste Land." In "A Game of Chess," Sweeney is mainly portrayed in negative shades as an anti-hero of the modern age, prone to primitive instincts. The main characteristic of the early period of T. Eliot's work is that the inhabitants of the poet's modern society are described as irregular, meaningless, insensitive, and empty beings. Love has been replaced by material wealth for the members of that community. Sweeney, as an immoral and uneducated being, has no understanding of culture, civilization, and rational thinking. There are certain hypotheses about the etymology of the word Sweeney. According to H. Nancy, it sounds like the word swine. "First, the name "Sweeney" not only has a sound which is common, prosaic, unmusical, perhaps even vulgar, but also it evokes the word "swine" with its connotations of bestial and gross physicality, ugliness, dirtiness, and stupidity." [Critical essays on T.S. Eliot: the Sweeney motif, 1985:150] G. Smith points out that the title is inspired by the name of the protagonist of the horror novel " The String of Pearls" written by T. P. Prest: "Todd, the demon barber of Fleet Street, created by T. P. Prest in the 1840s, was a shock-headed villain in the trade of butchering his clients to make meat pies." [Smith, Grover, 1971:45] According to Conrad, Sweeney was named after Stephen O'Donnell, an Irishman who once worked as Eliot's boxing teacher. [Richard March, Tambimuttu, 1949:21] In the article, his coach is connected with the physical strength because he once blackened T. Eliot's eyes. Everett Gillis introduces Sweeney as a man of modern society who represents the degradation of the spiritual world: "Eliot's most familiar symbol of gross materialism and vulgarity of contemporary civilization.... modern man in all his grossness and spiritual ineptitude." [Critical essays on T.S. Eliot: the Sweeney motif,1985:228]

Another notable name in T.S. Eliot's poetry is Prufrock. There are different approaches to the title of the poem "The Love Song of J. Alfred Prufrock" published in 1915. Prufrock, an aristocrat, is an anti-romantic hero who is completely cut off from the society he lives. The title of the poem is ironic. The absurdity of the title suggests that the essence of the poem is based on abstract ideas. 
Prufrock, characterized as a spiritually weak personality, is deprived of love and care. It is not a love song, but the heartbreaking groans of Prufrock's inner anguish. Eliot's poem is claimed to be based on the title of "The Love-song of Har-Dyal" by Rudyard Kipling. In 1959, at a meeting organized by the Kipling Society, T.S. Eliot discussed the author's influence on his poetry. "Traces of Kipling appear in my mature verse where no diligent scholarly sleuth has yet observed them, but which I am myself prepared to disclose. I once wrote a poem called "The Love Song of J. Alfred Prufrock": I am convinced that it would never have been called "Love Song" but for a title of Kipling's that stuck obstinately in my head: "The Love Song of Har Dyal".[ Eliot, T.S., 1959:9] F. Ruth, on the other hand, has a completely different view concerning the title of the poem: "His name is a play upon the words "proof "and "rock". The Germanic "Alfred" means a good counselor. And this persona is rock proof as buildings are fireproof. He is a figure as weak as himself who became the rock upon which Christ would build this Church. The J. is perhaps for Judas- another deceived Adam. [Ferrell, Ruth, 1972:48]

"Gerontion" (1920) is the other poem written in the style of a dramatic monologue by T.S. Eliot. Here Gerontion is described as an old man living in the period of the First World War. Gerontion means a little man in Greek translation. T. Eliot originally called the poem "Gerausia." Gerausia was associated with the name of the council of elders in Sparta. At Ezra Pound's suggestion, the name was replaced by a new one. The old man compares his memories with the current society. For him, life has no meaning, and he does not feel like a whole person. Gerontion is angry at the greedy society, where the material world is superior to the spiritual world, and religious ignorance prevails.

The woman depicted in the poem "Aunt Helen" (1917) is the complete opposite of Helen portrayed in Greek mythology. The mythical image Helen, who is an incomparably beautiful and irresistible woman, is compared to a woman who has no beauty. She can only be proud of her luxurious mansion. Helen of modern times is a poor being who only exists physically.

T.S. Eliot keeps the names of the poems as they are in original languages. "Melange Adultere de Tout" (General Adultery), "Lune de Miel" (Honeymoon), and "Le Directeur" (Director) were written in French. The title of the poem "La Figlia Che Piange" (1916) is translated from Italian as "a weeping woman." G.Smith stated: "While Eliot was travelling in Europe in 1911, he visited a museum in Italy possessing a stele designated, according to a friend who suggested that he take a look at it, "La Figlia che Piange" (young girl weeping)." [Smith, Grover,1971:26] Eliot visited Italy in the late summer of 1911, but he did not have a chance to see the monument, so he decided to write a poem about a stone pillar that he had not seen and imagined. H. Gardner supported the same view: "The poem is actually about a statue of a weeping girl, which the poet missed seeing in a museum in Italy." [Gardner, Helen. The art of T.S. Eliot, 1949:26] Considering it, many critics have controversial ideas about whether the girl depicted in the poem is real or imaginary. Picasso's painting "The Weeping Woman" directly resonates with the title of the poem too. Picasso portrayed a woman ugly and in fragmented bright colors to visualize a weeping woman in mind. In this poem, Eliot poetically reflects the subconscious feelings of a woman and her estranged lover.

Thomas Eliot's religious conversion influenced his poetry dramatically. The titles of such poetic examples as "Journey of the Magi," "A Song for Simeon," "Ash Wednesday" create an associativesemantic connection with the main idea. In the poem "Journey of the Magi,"(1927) the poet described the long and difficult journey of three sages to the place where Jesus was born. The journey of the wise men is clearly described in Matthew 2: 9-11: "After they had heard the king, they went on their way, and the star they had seen when it rose went ahead of them until it stopped over the place where the child was. When they saw the star, they were overjoyed. On coming to the house, they saw the child with his mother Mary, and they bowed down and worshiped him. Then they opened their treasures and presented him with gifts of gold, frankincense, and myrrh." [The Holy Bible, 2013:1188-1189] "A Song for Simeon" (1928) refers to the image of the believer Simeon in Luke's Gospel. The second chapter of Luke's Gospel gives information about a righteous believer named Simeon. He was informed by God that he would not die until he saw Christ. Inspired, Simeon goes to the temple, takes the newborn in his arms, and prays: "This child is destined to cause many in Israel to fall, and many others to rise. He has been sent as a sign from God, but many will oppose him. As a result, the deepest thoughts of many hearts will be revealed. And a sword will pierce your very soul." [The Holy Bible, 2013:1276]

It is clear from the title of the poem "Ash Wednesday" (1930) that we, the readers, will go on a religious journey here. In Christianity, from the 4th century onwards, the Orthodox Church called forty days before Easter the Great Diet, and this is due to Jesus' fasting in the wilderness, as recorded 
at Matthew 4:2. Except for Sundays, the Great Diet begins on Ash Wednesday and lasts until the last Sunday of Easter. In the poem, the new believer turns his face to eternal existence.

The title of the poem "Marina" is taken from Shakespeare's tragicomedy "Pericles, Prince of Tyre." This poem is reminiscent of the scene in Shakespeare's play in which Pericles encounters with his lost daughter. The poem deals with the enduring bond between a father and a daughter. Marian, Pericles' daughter, is a heroine who lost her father at birth and faced various challenges in life. In the fifth act of Shakespeare's play, the Prince of Tyre reveals that the girl dancing in front of him is his child. She looked like his wife who died after giving birth. He is very pleased to meet his daughter. She was named Marina because she was born by the sea. Marina means sea. The girl depicted in the poem embodies the triumph of salvation and peace. Pericles' encounter with Marina gives a subliminal message in the poem. The girl introduced her father to a completely new world - a divine kingdom and took him to a place where he could distinguish his friend from his enemy, where his soul was purified. Marina is an indication of the resurrection here. It should be noted that the poet later discovered a new world for himself due to conversion in religion.

"Four Quartets" is considered one of the largest poems of T.S. Eliot's poetry. The title is associated with the musical term "quartets." A quartet is a music played or sung to the accompaniment of four instruments or performers. The epic consists of four poems, each consisting of five parts. Although "Burnt Norton" was published in 1935, other poems in the quartet were written during World War I between 1939-1945. The similarity of the poems in the quartet is that the titles of each poem are related to the real places. Norton was a mansion in the Cotswold Mountains in Gloucester. The name of the burned Norton is associated with landlord William Kate, who burnt his property. Wealthy W. Kate fell in love with a housemaid, left his wife and children, and moved to Norton with his mistress. He turned Norton into a magnificent, luxurious area and planted a large garden. $\mathrm{He}$ betrayed his new wife with a young servant in the same year. As a result, he became addicted to alcohol and was left alone. The landlord, who had lost his whole life, set fire to his mansion in despair, and everything inside the house, including himself, burned to ashes. Helen Gardner in her book "The Composition of the Four Quartets" states: "No trace remains today of the mansion Keyte built; the name that commemorates the catastrophe is attached to the estate and the original farmhouse which through centuries has been expanded into a family house." [Gardner, Helen. The composition of Four quartets,1978:36] Eliot urges people to pay attention to the present moment and tries to convince them of the existence of universal order. According to him, only after understanding the nature of time and order, human beings will be saved by God.

Another poem included in the quartet is called "East Coker". East Coker is one of the places that play an important role in the life of the poet. He visited here in 1937. The poet's ancestors settled in this place. In 1669, Eliot's ancestor, Andrew Eliot, left East Cocker and moved to America. "The place held particular importance to Eliot and his family because Andrew Eliot, Eliot's ancestor, left the town to travel to America in 1669." [Pinion, F.B.,1986:6] The artist focuses on the enrichment of the inner world, religious world, the attachment to the ancestors.

The third poem of the quartet is called "The Dry Salvages". The epigraph states that the dry salvages are a group of small islands in the northeastern Gulf of Massachusetts, where the poet spent his childhood. In this sense, the poem is more autobiographical than other sections. In his book, "The composition of the Four Quartets," H. Gardner stated that the area described in that poem had played an important role in the poet's life: "In the summer, Eliot's family migrated every year from the heat of St. Louis to the Massachusetts or Maine coast, usually to the seaport of Gloucester, Massachusetts. Here in 1896, on Eastern Point, the spit of land which forms the eastern arm of Gloucester's deep harbour, Eliot's father built a house for the family's summer home. The Atlantic off the great promontory of Cape Ann is studded with rocks and reefs. It is a dangerous and difficult coast, as well as a supremely beautiful one. Eliot and his older brother, Henry, were taught to sail on its waters by an ancient mariner of Gloucester and became expert at navigating its hazards. Later, they sailed in Henry's boat, the Esla, and in his Harvard days Eliot sailed in variations with a college friend, Harold Peters." [Gardner, Helen. The composition of Four quartets, 1978:50] In the poem, the poet recalls his childhood memories by traveling to the past. The work, which has a religious character, vividly expresses the belief in eternity and divine power.

The fourth poem of the quartet "Little Gidding" is also connected with the name of the place. Little Gidding functioned as a small Anglican community in England in the 17th century and was 
burned during the Civil War. B. Henry explained Gidding's description like that: "The community's unique blend of religious discipline and family life makes the place a peculiarly powerful symbol of reconciliation between the way of Negation and the way of Affirmation, between the practice of austerity and the acceptance of life's revelatory richness, the way of the fire, and the way of the rose. The place is now also a symbol of past conflicts resolved- the conflict between king and Parliament, Episcopacy and Dissent, the Catholic and the Evangelical strains in Christian doctrine and practice." [Blamires, Harry, 1969:122] Humanity and time are interconnected in this poem.

Conclusions. Thus, in the poetry of Thomas Eliot, the name and the character form a dialectical unity, and there is a semantic denial in the naming of anti-heroes. The poet widely used irony in naming any work. It is not debatable that the influence of place names and their connection to the literary text in the titles are vividly described.

\section{REFERENCES}

1. Blamires, Harry. Word unheard: a guide through Eliot's 'Four quartets'. London, Methuen, 1969

2. Critical essays on T.S. Eliot: the Sweeney motif. Boston, Mass.: G.K. Hall, 1985

3. Eliot, T. S. "The Unfading Genius of Rudyard Kipling" in Kipling Journal (March 1959), 9.

4. Eliot, T. S. (Thomas Stearns), 1888-1965). Inventions of the March Hare: poems 1909-1917. New York: Harcourt Brace, 1997

5. Eliot, T. S. The Letters of T. S. Eliot. (New York: Harcourt, Brace Jovanovich, 1988). 1:135.

6. Ferrell, Ruth K. T. S. Eliot and the tongues of fire; a scholarly study. New York, Exposition Press, 1972

7. Gardner, Helen. The art of T.S. Eliot. London, Cresset Press, 1949.

8. Gardner, Helen. The composition of Four quartets. New York: Oxford University Press, 1978

9. Pinion, F. B. T. S. Eliot Companion. London: MacMillan, 1986

10. Richard March, Tambimuttu. T. S. Eliot: A Symposium from Conrad Aiken and Others. Chicago, H. Regnery Co., 1949

11. Smith, Grover. T.S. Eliot's poetry and plays; a study in sources and meaning. Chicago, University of Chicago Press, 1971.

12. The Holy Bible. The Church of Jesus Christ of Latter-day Saints, Salt Lake City, Utah, USA, 2013

13. The Letters of T. S. Eliot, ed. Valeria Eliot, Vol. 1: 1898-1922 [London, Faber and Faber, 1988

14. Williamson, George, 1898-1968. A reader's guide to T.S. Eliot; a poem-by-poem analysis. New York, Farrar, Straus \& Giroux, 1965

15. William Shakespeare. Pericles, Pince of Tyre. Washington Square Press, 2005 